\title{
Sensitivity of Different Cattle Breeds to the Infestation of Cattle Ticks Amblyomma variegatum, Rhipicephalus microplus, and Hyalomma spp. on the Natural Pastures of Opkara Farm, Benin
}

\author{
Roland Eric Yessinou ${ }^{(D},{ }^{1}$ Camus Adoligbe, ${ }^{1}$ Yao Akpo, ${ }^{2}$ Justin Adinci, \\ Issaka Youssao Abdou Karim, ${ }^{1}$ and Souaïbou Farougou ${ }^{1}$ \\ ${ }^{1}$ University of Abomey-Calavi (UAC), Polytechnic School of Abomey-Calavi (EPAC) Production and Animal Health Department, \\ Applied Biology Research Laboratory (LARBA), 01 P.O. Box 2009 Cotonou, Benin \\ ${ }^{2}$ Laboratory of Ecology, Health and Animal Production, Faculty of Agronomy, University of Parakou, P.O. Box 123 Parakou, Benin
}

Correspondence should be addressed to Roland Eric Yessinou; eric.yessinou@uac.bj

Received 5 October 2017; Revised 20 January 2018; Accepted 13 February 2018; Published 25 March 2018

Academic Editor: José F. Silveira

Copyright (C) 2018 Roland Eric Yessinou et al. This is an open access article distributed under the Creative Commons Attribution License, which permits unrestricted use, distribution, and reproduction in any medium, provided the original work is properly cited.

\begin{abstract}
A study was carried out on the Opkara (Benin) cattle farm on 64 cattle of four different breeds (16 individuals per breed) from June to December 2016. During this study, three tick species were found in different numbers, Amblyomma variegatum (732), Rhipicephalus microplus (8079), and Hyalomma spp. (208), with parasitic intensity of $11.90,126.23$, and 3.25, respectively. The interracial comparison of the tick infestation between the cattle showed a significant difference $(P<0.001)$. However, Girolando was more infested than all the cattle breeds. Infestation of A. variegatum, R. microplus, and Hyalomma spp. on the Girolando was, respectively, $19.43 \pm 2.71,171.25 \pm 23.50$, and $7.12 \pm 0.63$, but the Borgou were less infested. Borgou breed females were more infested by A. variegatum ( $4.41 \pm 1.14)$ than females Girolando $(4.20 \pm 0.90)$. The Crossbred and Azawak females were less infested $(P<0.01)$. The mean of $A$. variegatum on Borgou, Azawak, Crossbred, and Girolando calves was 1.29 $\pm 0.35,0.66 \pm 0.26,1.37 \pm 0.37$, and $2.25 \pm 0.48(P<0.01)$, respectively. The results of this study can be exploited to include genetic and nongenetic approaches to tick control.
\end{abstract}

\section{Introduction}

Benin is an agricultural country and livestock play a predominant role in agricultural production [1]. In addition to meat and milk production, cattle are used by farmers to plow the land. The performance of these cattle is negatively affected by ectoparasites. For instance, tick-borne diseases have significant impact on animal productivity; they cause mortality and enormous economic losses for livestock farmers [2]. The acaricides used by breeders for ticks management are not always effective [3]. Chemicals used have a serious impact on the environment and on the safety of meat and milk products that are consumed [4]. Also, access to chemical treatments is not affordable for the poorest breeders. Ticks, especially Rhipicephalus microplus, have developed resistance against most of the acaricides used for their control [3]. Many in vitro studies on the effect of the mixture of essential oils and plant on engorged female of $R$. microplus have shown satisfactory results. However, on field essay needs to be conducted to extend such results [5]. Thus, the only rapid control method available now to breeders is the application of synthetic acaricidal molecules [6]. To control these parasites, other control methods can be explored such as the selection of tick-resistant cattle. Studies done on Nkedi Zebu and Ankole exposed to tick infestation have shown intraracial differences in tick load [7], and a difference in infestation was noted according to the cattle ages. The works done by Mattioli et al. [8] on N'Dama, Gobra Zebu, and their crossbred products showed an interracial difference of tick infestations, suggesting that the selection of the cattle can be also based on ticks resistance. Animals selected for their greater resistance to R. microplus consistently exhibited a lesser load than their 
congenerics in whom a resistance criterion was not taken into account [9]. The results obtained by Piper et al. [10] on ticks confirm that the expression of certain genes in the skin of bovines reduces the infestation of the tick of the cattle R. microplus. Other studies show that cattle Bos indicus have developed resistance against Amblyomma variegatum [11]. In any case, the selection of tick-resistant animals can reduce the devastating effect of tick infestation. This method of control is not harmful to the environment, entails no additional costs, and can be a viable solution for the livestock sector. On the other hand, in most cases, ticks and vectors of trypanosomiasis are found on the same pastures. The selection of resistant animals is not only for tick management but also for limiting the tick resistance to acaricides and break down the intensive use of synthetic products for these ectoparasites' control. This study aims at assessing the level of infestation of different tick species in the same environment as well as the influence of breeds and sex.

\section{Materials and Methods}

2.1. Study Area. The works were carried out in the communes of Tchaourou northeast of Benin. This locality belongs to the agroecological zone (Cotton Zone of Center Benin or Zone $\mathrm{V})$. The commune of Tchaourou is located in the department of Borgou at $11^{\circ} 08^{\prime}$ north latitude and $2^{\circ} 56^{\prime}$ east longitude. It has an area of $7,256 \mathrm{~km}^{2}$; it represents $28 \%$ of the total area of this department and about $6.5 \%$ of the national territory. It is bounded on the north by the municipalities of Parakou, Pèrèrè, and N'Dali, on the south by the commune of Ouèssè, on the east by the Federal Republic of Nigeria, and on the west by the municipalities of Bassila and Djougou. This strategic geographical position is undoubtedly a major asset to be exploited by the municipal authorities for the promotion of the local economy. Like the other communes of the department of Borgou, the commune of Tchaourou is subject to the influence of the South Sudanese climate. It is a modal united climate characterized by a dry season and a wet season. Rainfall totals vary between 1100 and $1200 \mathrm{~mm} /$ year and range from 6 to 7 months wet during the year. The ecological preferences of ticks are variable, as each species needs specific environmental conditions enabling it to live in a given biotope, which influences its geographical distribution. Several ecological factors influence the survival and development of ticks, particularly temperature, relative humidity, and vegetation cover. This pluviometry distribution may, therefore, favor the emergence of certain species of the tick in this commune (Figure 1).

2.2. Tick Collection. The study carried out took into account the four different cattle races existing on the Opkara breeding farm. A total of 64 animals ( 4 bulls, 4 cows, 4 calves, and 4 velles by breed) were randomly selected from the animals to serve as a study sample. The animals were reared on the same holding and were brought in the same natural pasture. Tick sampling was carried out weekly on each animal for 20 weeks from July to December 2016, a period of rainy season and dry season. The animals were kept in the contention corridors to collect ticks in the anatomical region. Acaricides were not used during the two weeks prior to the experiment and during its duration. The dermatological lesions as well as the other, clinical signs observed on the animals were noted but we did not make the case in this study. The animals consist of Borgou (Somba or Lagunaire $\times$ Zebu White Fulani), Azawak $($ Zebu), Crossbred (Borgou $\times$ Girolando), and Girolando (Gyr $\times$ Holstein).

2.3. Conservation and Identification of Ticks. Ticks were collected manually from each animal using pincers on the seven predefined parts (head and neck, ears, back and croup, abdominal, ventrogenital, tail, and legs) on each animal by a team after its restraint. The ticks were stored in seven vials containing $70 \%$ ethanol and labeled according to the predefined part of each animal. Another label with necessary information was inserted directly into each vial having sample before closing completely. The information was marked in pencil and includes the date of collection, animal identification number, and other relevant data. The species identification was carried out using the identification key elaborated by Walker et al. [12] with an electronic binocular microscope (Olympus) at 100x magnification.

2.4. Statistical Analysis. The data was saved in Excel 2007; the $\mathrm{R}$ software was used to analyze the data. The abundance and mean parasitic intensity were calculated. For the mean number of ticks per animal, the factors of variation considered were tick species, bovine breed, tick life stage, cattle anatomy region, and cattle infestation index. For each variation factor, the $F$ test was used to determine its significance and the means were compared two by two using Student's $t$-test. Evaluation of ticks load was as follows:

(i) Abundance $(A)$ is the ratio of the total number of individuals of a parasitic species $(n)$ to the total number of individuals examined $(H) . A=n / H$.

(ii) The mean parasitic intensity $(I)$ corresponds to the ratio of the total number of individuals of a parasitic species $(n)$ in a host sample to the number of infested $(N)$ hosts in the sample. $I=n / N$. For the mean parasitic intensities $(I)$, the classification adopted is that of Bilong-Bilong and Njiné [13]:

(a) $I<10$ : mean parasitic intensity is very low,

(b) $10<I<50$ : mean parasitic intensity is low,

(c) $50<I<100$ : mean parasitic intensity is average,

(d) $I>100$ : mean parasitic intensity is high.

\section{Result}

3.1. Abundance and Mean Parasitic Intensity for Tick Species. A total of 9049 ticks were collected, and the tick species encountered in the study area were A. variegatum, $R$. microplus, and Hyalomma spp. The number of ticks by species, their abundance, and the mean parasitic intensity are described in Table 1.

3.2. Infestation Index of the Tick's Species Parasite of Cattle. The Girolando infestation index by $R$. microplus is three 
TABLE 1: Abundance and mean parasitic intensity for tick's species.

\begin{tabular}{lccc}
\hline Ticks species & Number of ticks & Abundance (\%) & $\begin{array}{c}\text { Mean parasitic } \\
\text { intensity }(I)\end{array}$ \\
\hline A. variegatum & 762 & 8.42 & 11.90 \\
R. microplus & 8079 & 89.28 & 126.23 \\
Hyalomma spp. & 208 & 2.29 & 3.25 \\
\hline
\end{tabular}

Mean parasitic intensity $(I)$ corresponds to the ratio of the total number of individuals of a parasite species $(n)$ in a sample of hosts on the number of infested hosts $(N)$ in the sample. $I=n / N$.

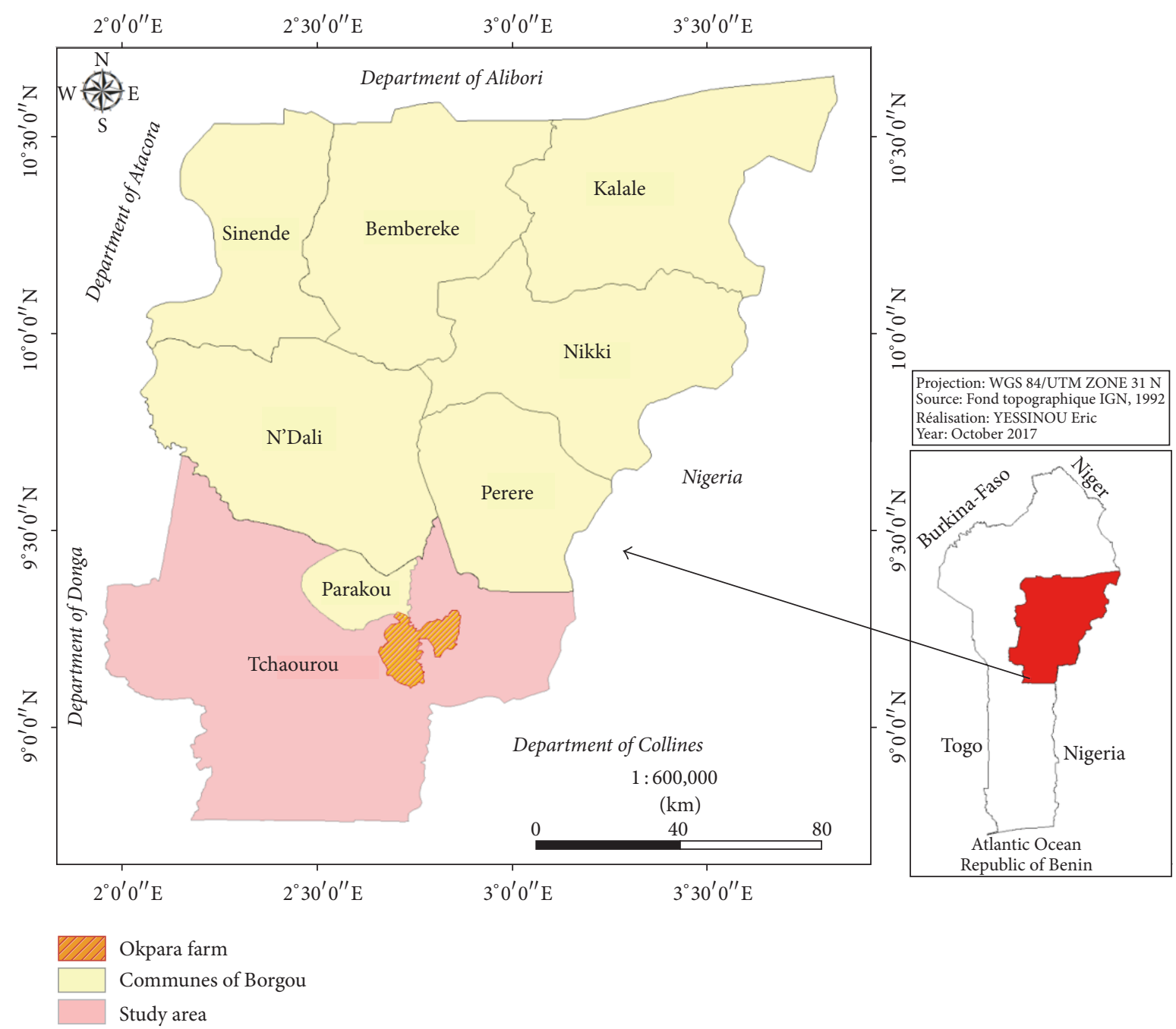

FIgURE 1: The map of Benin showing the district (Okpara) where experiment on cattle breed was carried out.

times higher than that of the Borgou. This latter represents the lowest index in contrast to the infestation index by $A$. variegatum which was 2.20 in Girolando followed by Borgou which was 1.39 (Table 2).

\subsection{Influence of Breed Cattle on Tick's Different Species Infesta-} tion. The effect of the cattle breed on tick infestation showed that Girolando cattle are more infested $(P<0.01)$ by ticks A. variegatum $(19,43)$ compared to breeds Borgou (12.31), Azawak (8.25), and Crossbred (7.68), which all have similar rates of infestation. Likewise, infestations of $R$. microplus in cattle of the breeds Borgou (62.43), Azawak (98.81), and Crossbred (102.56) are lower than Girolando (171.25) $(P<$ 0.001). In addition, infestation of tick Hyalomma spp. was high on Girolando breed (7.12) compared to that of the Borgou (2.31), Azawak (1.18), and Crossbred (1.93) (Table 3).

\subsection{Influence of Cattle Breed on Infestation of Different Stasis} of Tick. Imaginary stasis is as follows: infestation means of Borgou, Azawak, Crossbred, and Girolando by A. variegatum and $R$. microplus females are significantly different $(P<0.001)$ with the highest average on Girolando, but no 
TABLE 2: Infestation index of the tick's species parasite of cattle.

\begin{tabular}{lccc}
\hline Cattle & A. variegatum & $\begin{array}{c}\text { Infestation index } \\
\text { R. microplus }\end{array}$ & Hyalomma spp. \\
\hline Borgou & 1.39 & 8.14 & 0.26 \\
Azawak & 0.93 & 12.82 & 0.13 \\
Crossbred & 0.87 & 13.20 & 0.22 \\
Girolando & 2.20 & 23.02 & 0.81 \\
\hline
\end{tabular}

${ }^{1}$ Infestation of the animal/mean infestation of the herd.

TABLE 3: Influence of breed cattle on tick different species infestation.

\begin{tabular}{|c|c|c|c|c|c|}
\hline Tick species & $\begin{array}{c}\text { Borgou } \\
\text { Means } \pm \text { SE }\end{array}$ & $\begin{array}{c}\text { Azawak } \\
\text { Means } \pm \text { SE }\end{array}$ & $\begin{array}{c}\text { Crossbred } \\
\text { Means } \pm \text { SE }\end{array}$ & $\begin{array}{c}\text { Girolando } \\
\text { Means } \pm \text { SE }\end{array}$ & Sig \\
\hline A. variegatum & $12.31 \pm 3.30^{\mathrm{b}}$ & $8.25 \pm 1.40^{\mathrm{b}}$ & $7.68 \pm 1.10^{b}$ & $19.43 \pm 2.71^{\mathrm{a}}$ & $* *$ \\
\hline R. microplus & $62.43 \pm 13.15^{\mathrm{b}}$ & $98.81 \pm 16.76^{\mathrm{b}}$ & $102.56 \pm 9.11^{\mathrm{b}}$ & $171.25 \pm 23.50^{\mathrm{a}}$ & $* * *$ \\
\hline Hyalomma spp. & $2.31 \pm 0.47^{\mathrm{b}}$ & $1.18 \pm 0.34^{\mathrm{b}}$ & $1.93 \pm 0.30^{\mathrm{b}}$ & $7.12 \pm 0.63^{\mathrm{a}}$ & $* * *$ \\
\hline
\end{tabular}

SE: standard error; ${ }^{* *} P<0.01 ;{ }^{* * *} P<0.001$. a, b: means with the same letters within lines are not significantly different, $P>0.05$ (averages of the same line, followed by the same letter, do not differ significantly at the $5 \%$ level).

TABLE 4: Influence of cattle breed on infestation of different stasis of tick.

\begin{tabular}{|c|c|c|c|c|c|c|}
\hline Ticks species & Stasis & $\begin{array}{c}\text { Borgou } \\
\text { Means } \pm \text { SE }\end{array}$ & $\begin{array}{c}\text { Azawak } \\
\text { Means } \pm \text { SE }\end{array}$ & $\begin{array}{c}\text { Crossbred } \\
\text { Means } \pm \text { SE }\end{array}$ & $\begin{array}{c}\text { Girolando } \\
\text { Means } \pm \text { SE }\end{array}$ & Sig \\
\hline \multirow{3}{*}{ A. variegatum } & Males & $1.96 \pm 0.46^{\mathrm{a}}$ & $2.59 \pm 0.79^{\mathrm{a}}$ & $1.53 \pm 0.32^{\mathrm{a}}$ & $2.4 \pm 0.46^{\mathrm{a}}$ & NS \\
\hline & Females & $2.93 \pm 0.64^{\mathrm{b}}$ & $2.00 \pm 0.32^{\mathrm{b}}$ & $2.06 \pm 0.39^{\mathrm{b}}$ & $6.34 \pm 1.30^{\mathrm{a}}$ & $* * *$ \\
\hline & Nymphs & $0.62 \pm 0.23^{\mathrm{ab}}$ & $0.15 \pm 0.07^{\mathrm{b}}$ & $0.25 \pm 0.08^{\mathrm{b}}$ & $0.96 \pm 0.25^{\mathrm{a}}$ & $* *$ \\
\hline \multirow{3}{*}{ R. microplus } & Males & $2.00 \pm 0.39^{\mathrm{a}}$ & $2.40 \pm 0.44^{\mathrm{a}}$ & $2.18 \pm 0.40^{\mathrm{a}}$ & $2.06 \pm 0.36^{\mathrm{a}}$ & NS \\
\hline & Females & $32.37 \pm 5.57^{\mathrm{b}}$ & $52.93 \pm 9.50^{\mathrm{b}}$ & $55.84 \pm 8.22^{\mathrm{b}}$ & $97.59 \pm 13.47^{\mathrm{a}}$ & $* * *$ \\
\hline & Nymphs & $1.18 \pm 0.37^{\mathrm{ab}}$ & $1.15 \pm 0.31^{\mathrm{ab}}$ & $0.35 \pm 0.11^{\mathrm{b}}$ & $2.06 \pm 0.40^{\mathrm{a}}$ & $* *$ \\
\hline \multirow{3}{*}{ Hyalomma spp. } & Males & $0.46 \pm 0.14^{\mathrm{b}}$ & $0.28 \pm 0.09^{\mathrm{b}}$ & $0.28 \pm 0.08^{\mathrm{b}}$ & $1.15 \pm 0.23^{\mathrm{a}}$ & $* * *$ \\
\hline & Females & $0.59 \pm 0.13^{\mathrm{b}}$ & $0.31 \pm 0.09^{\mathrm{b}}$ & $0.46 \pm 0.11^{\mathrm{b}}$ & $2.15 \pm 0.41^{\mathrm{a}}$ & $* * *$ \\
\hline & Nymphs & $0.12 \pm 0.05^{\mathrm{ab}}$ & $0.00 \pm 0.00^{\mathrm{b}}$ & $0.21 \pm 0.07^{\mathrm{ab}}$ & $0.25 \pm 0.08^{\mathrm{a}}$ & * \\
\hline
\end{tabular}

SE: standard error; ${ }^{\mathrm{NS}} \mathrm{P}>0.05 ;{ }^{*} \mathrm{P}<0.05 ;{ }^{* *} \mathrm{P}<0.01 ;{ }^{* * *} \mathrm{P}<0.001$. a, b, and ab: means with the same letters within lines are not significantly different, $P>0.05$ (averages of the same line, followed by the same letter, do not differ significantly at the $5 \%$ level).

significant difference was noted on male ticks. However, with Hyalomma spp., a significant difference was reported with infestation mean. Preimaginary stasis is as follows: mean infestations of Borgou, Azawak, Crossbred, and Girolando cattle by A. variegatum, R. microplus, and Hyalomma spp. are significantly different $(P<0.001)$. The nymphs of ticks found on the body of Girolando are more numerous than those of the other races in our study (Table 4). In general, it appears from this analysis that the $R$. microplus species was the most abundant and the most infesting to all stasis and that on the Girolando cattle. The males of A. variegatum and $R$. microplus were more present on Azawak cattle than other breeds. However, Hyalomma spp. were less infesting than other tick species.

3.5. Infestation of Anatomical Regions of Cattle by Different Tick Species. The mean of the tick species collected in the anatomical regions of the cattle breeds is presented in Table 5 . On head and neck, the mean infestation of tick's R. microplus is significantly different $(P<0.001)$ with the highest average noted on Girolando. However, the mean of Hyalomma spp. on the cattle breeds has been significantly different at the $5 \%(P<$ 0.05 ). Cattle ears have been also infested by $A$. variegatum, $R$. microplus, and Hyalomma spp. but $R$. microplus is the highest mean of infestation and was found on the Girolando $(P<0.001)$. The mean of infestation $R$. microplus on the back and rump of Borgou is $4.21 \pm 0.78$. It represents the lowest infestation of this part of the body, but the highest infestation is noted on the Girolando $(7.84 \pm 1.06)(P<0.05)$. On the Girolando the level infestation of $A$. variegatum on the back and the rump has been of $1.25 \pm 0.26$ followed by Borgou $(0.93 \pm 0.24)(P<0.01)$. At level of the abdominal region, no significant differences exist between the mean of A. variegatum populations collected from the different cattle $(P>0.05)$. Nevertheless, in the two other tick species, $R$. microplus and Hyalomma spp., a significant difference was noted on the infestation of cattle. Girolando $(9.68 \pm 1.16)$ and Azawak (6.62 \pm 1.03$)$ were more infested by $R$. microplus than the other two races. The Girolando are more infested by the Hyalomma spp. $(1.06 \pm 0.27)$ than the Borgou $(0.37 \pm 0.13)$. Ticks $A$. variegatum that were collected in the ventrogenital region were more numerous in Girolando $(2.09 \pm 0.39)$ than 
TABLE 5: Infestation of anatomical regions of cattle by different tick species.

\begin{tabular}{|c|c|c|c|c|c|c|}
\hline Anatomical regions & Ticks species & $\begin{array}{c}\text { Borgou } \\
\text { Means } \pm \text { SE }\end{array}$ & $\begin{array}{c}\text { Azawak } \\
\text { Means } \pm \text { SE }\end{array}$ & $\begin{array}{c}\text { Crossbred } \\
\text { Means } \pm \text { SE }\end{array}$ & $\begin{array}{c}\text { Girolando } \\
\text { Means } \pm \text { SE }\end{array}$ & Sig \\
\hline \multirow{3}{*}{ Head and neck } & A. variegatum & $1.37 \pm 0.46^{\mathrm{a}}$ & $0.78 \pm 0.16^{\mathrm{a}}$ & $0.71 \pm 0.17^{\mathrm{a}}$ & $1.84 \pm 0.36^{\mathrm{a}}$ & NS \\
\hline & R. microplus & $5.78 \pm 1.08^{\mathrm{b}}$ & $7.81 \pm 1.38^{\mathrm{b}}$ & $9.78 \pm 1.61^{\mathrm{b}}$ & $16.09 \pm 2.29^{\mathrm{a}}$ & $* * *$ \\
\hline & Hyalomma spp. & $0.12 \pm 0.06^{\mathrm{ab}}$ & $0.06 \pm 0.04^{\mathrm{b}}$ & $0.03 \pm 0.03^{\mathrm{b}}$ & $0.28 \pm 0.09^{\mathrm{a}}$ & * \\
\hline \multirow{3}{*}{ Ears } & A. variegatum & $1.00 \pm 0.30^{\mathrm{ab}}$ & $0.65 \pm 0.14^{\mathrm{b}}$ & $0.62 \pm 0.16^{\mathrm{b}}$ & $1.68 \pm 0.37^{\mathrm{a}}$ & * \\
\hline & R. microplus & $4.34 \pm 0.81^{\mathrm{b}}$ & $8.46 \pm 2.01^{\mathrm{b}}$ & $6.84 \pm 1.29^{\mathrm{b}}$ & $17.34 \pm 3.96^{\mathrm{a}}$ & $* * *$ \\
\hline & Hyalomma spp. & $0.15 \pm 0.06^{\mathrm{a}}$ & $0.12 \pm 0.05^{\mathrm{a}}$ & $0.15 \pm 0.07^{\mathrm{a}}$ & $0.18 \pm 0.08^{\mathrm{a}}$ & NS \\
\hline \multirow{3}{*}{ Back and croup } & A. variegatum & $0.93 \pm 0.24^{\mathrm{a}}$ & $0.37 \pm 0.08^{b}$ & $0.31 \pm 0.10^{\mathrm{b}}$ & $1.25 \pm 0.26^{\mathrm{a}}$ & $* *$ \\
\hline & R. microplus & $4.21 \pm 0.78^{\mathrm{b}}$ & $4.62 \pm 0.98^{\mathrm{b}}$ & $5.34 \pm 0.86^{\mathrm{ab}}$ & $7.84 \pm 1.06^{\mathrm{b}}$ & $*$ \\
\hline & Hyalomma spp. & $0.28 \pm 0.11^{\mathrm{b}}$ & $0.12 \pm 0.05^{\mathrm{b}}$ & $0.28 \pm 0.08^{\mathrm{b}}$ & $1.06 \pm 0.22^{\mathrm{a}}$ & $* * *$ \\
\hline \multirow{3}{*}{ Abdominal } & A. variegatum & $0.50 \pm 0.24^{\mathrm{a}}$ & $0.46 \pm 0.14^{\mathrm{a}}$ & $0.50 \pm 0.14^{\mathrm{a}}$ & $1.03 \pm 0.25^{\mathrm{a}}$ & NS \\
\hline & R. microplus & $4.18 \pm 0.74^{\mathrm{b}}$ & $6.62 \pm 1.03^{\mathrm{b}}$ & $5.15 \pm 0.80^{\mathrm{b}}$ & $9.68 \pm 1.16^{\mathrm{a}}$ & $* * *$ \\
\hline & Hyalomma spp. & $0.37 \pm 0.13^{\mathrm{b}}$ & $0.12 \pm 0.05^{\mathrm{b}}$ & $0.21 \pm 0.09^{\mathrm{b}}$ & $1.06 \pm 0.27^{\mathrm{a}}$ & $* * *$ \\
\hline \multirow{3}{*}{ Ventrogenital } & A. variegatum & $1.28 \pm 0.36^{\mathrm{ab}}$ & $1.06 \pm 0.25^{\mathrm{ab}}$ & $0.90 \pm 0.22^{\mathrm{b}}$ & $2.09 \pm 0.39^{\mathrm{a}}$ & $*$ \\
\hline & R. microplus & $9.78 \pm 1.99^{\mathrm{b}}$ & $18.21 \pm 3.73^{b}$ & $18.28 \pm 3.15^{\mathrm{b}}$ & $33.87 \pm 6.70^{\mathrm{a}}$ & $* *$ \\
\hline & Hyalomma spp. & $0.12 \pm 0.05^{\mathrm{a}}$ & $0.06 \pm 0.04^{\mathrm{a}}$ & $0.12 \pm 0.05^{\mathrm{a}}$ & $0.18 \pm 0.08^{\mathrm{a}}$ & NS \\
\hline \multirow{3}{*}{ Tail } & A. variegatum & $0.68 \pm 0.17^{\mathrm{a}}$ & $0.56 \pm 0.12^{\mathrm{a}}$ & $0.53 \pm 0.12^{\mathrm{a}}$ & $1.21 \pm 0.31^{\mathrm{a}}$ & NS \\
\hline & R. microplus & $4.96 \pm 0.91^{\mathrm{b}}$ & $8.50 \pm 1.76^{\mathrm{ab}}$ & $10.43 \pm 2.01^{\mathrm{ab}}$ & $12.28 \pm 2.09^{\mathrm{a}}$ & $*$ \\
\hline & Hyalomma spp. & $0.03 \pm 0.03^{\mathrm{b}}$ & $0.03 \pm 0.03^{\mathrm{b}}$ & $0.12 \pm 0.08^{\mathrm{ab}}$ & $0.31 \pm 0.09^{\mathrm{a}}$ & * \\
\hline \multirow{3}{*}{ Legs } & A. variegatum & $0.25 \pm 0.10^{\mathrm{b}}$ & $0.18 \pm 0.08^{\mathrm{b}}$ & $0.25 \pm 0.07^{\mathrm{b}}$ & $0.62 \pm 0.14^{\mathrm{a}}$ & $*$ \\
\hline & R. microplus & $2.09 \pm 0.46^{\mathrm{b}}$ & $2.65 \pm 0.64^{\mathrm{b}}$ & $2.18 \pm 0.51^{\mathrm{b}}$ & $5.00 \pm 0.89^{\mathrm{a}}$ & $* *$ \\
\hline & Hyalomma spp. & $0.06 \pm 0.04^{\mathrm{b}}$ & $0.06 \pm 0.04^{\mathrm{b}}$ & $0.03 \pm 0.03^{\mathrm{b}}$ & $0.31 \pm 0.11^{\mathrm{a}}$ & $* *$ \\
\hline
\end{tabular}

SE: standard error; ${ }^{\mathrm{NS}} P>0.05 ;{ }^{*} P<0.05 ;{ }^{* *} P<0.01 ;{ }^{* * *} P<0.001$. a, b, and ab: means with the same letters within lines are not significantly different, $P>0.05$ (averages of the same line, followed by the same letter, do not differ significantly at the $5 \%$ level).

in Borgou $(1.28 \pm 0.36)(P<0.05)$. The preference of $R$. microplus for the ventral genital region appears to be similar of the Azawak $(18.21 \pm 3.73)$ and the Crossbred $(18.28 \pm 3.15)$, but the Girolando $(33.87 \pm 6.70)$ are more infested. The presence of ticks was also noted on the cattle tail prospected. The mean of $R$. microplus was $12.28 \pm 2.09$, $10.43 \pm 2.01,8.50 \pm 1.76$, and $4.96 \pm 0.91$, respectively, in the Girolando, Crossbred, Azawak, and Borgou $(P<0.05)$. A lower infestation of Hyalomma spp. was noted on the tail of different races; however, they were high with Girolando $(0.31 \pm 0.09)$ followed by Crossbred $(0.12 \pm 0.08)$. These ticks were present at the same rate in the other two races. The $A$. variegatum ticks were found on cattle in varying degrees $(P<0.05)$. Mean of $R$. microplus observed on the legs of Borgou, Azawak, and Crossbred is similar but for Girolando $(P<0.05)$ was highly infested. A. variegatum and Hyalomma spp. were also found on the legs of cattle. The mean number of ticks per anatomical region calculated from the mean of ticks harvested in the study area showed that Girolando cattle are more attracted to ticks than other cattle breeds. It should also be noted that the anatomical regions (head and neck, ears, ventrogenital, and tail) are more infested with $R$. microplus in Girolando and other cattle. The Borgou are less infested by ticks than the Girolando, Crossbred, and Azawak (Table 5).

3.6. Influence of Sex of Cattle on Tick's Infestation. Infestation of each tick species according to the age and sex categories of the animals was also the subject of this study. Borgou breed females were more infested by $A$. variegatum $(4.41 \pm 1.14)$ than Girolando females (4.20 \pm 0.90$)$. The Crossbred and Azawak females have been less infested, respectively, in the order of $1.79 \pm 0.42$ and $1.33 \pm 0.38(P<0.01)$. In addition, no significant difference was noted between the infestation means of Borgou, Azawak, Crossbred, and Girolando males. The mean of A. variegatum on Borgou, Azawak, Crossbred, and Girolando calves was $1.29 \pm 0.35,0.66 \pm 0.26,1.37 \pm 0.37$, and $2.25 \pm 0.48(P<0.01)$, respectively. Girolando breeds have been more infested (1.75 \pm 0.36$)$, followed by Azawak $(1.00 \pm 0.25)$. Borgou breeds were the least infested by $A$. variegatum $(P<0.001)$. Tick $R$. microplus infestation was greater in male Girolando, Azawak, and Crossbred bovines with the respective mean of $54.79 \pm 19.66,38.62 \pm 12.99$, and $32.54 \pm 10.57$ than male bulls Borgou $25.37 \pm 6.84$. Ticks $R$. microplus collected from the Borgou, Azawak, Crossbred, and Girolando females have been in the order of $17.79 \pm 5.22$, $21.37 \pm 6.74,21.87 \pm 7.86$, and $39.79 \pm 13.38(P>0.05)$, respectively. In the calves also no significant differences were noted in infestation with $R$. microplus $(P>0.05)$. The infestation of the Girolando breeds was $21.87 \pm 6.65$ compared to $1.29 \pm 0.42$ on the Borgou breeds and has been the least abundant infestation followed by Azawak $5.12 \pm 1.85(P<$ 0.01) (Table 5). Hyalomma spp. ticks were less important on Azawak $(0.12 \pm 0.06)$ and Crossbred $(0.25 \pm 0.09)$ than Girolando (1.16 \pm 0.30$)$ and Borgou $(0.54 \pm 0.15)$ males $(P<$ $0.001)$. The cows of the four breeds were also exposed to the infestation of Hyalomma spp. $(P<0.01)$ and calves $(P<$ 
TABLE 6: Influence of sex of cattle on tick's infestation.

\begin{tabular}{|c|c|c|c|c|c|c|}
\hline Ticks species & Cattle & $\begin{array}{c}\text { Borgou } \\
\text { Means } \pm \text { SE }\end{array}$ & $\begin{array}{c}\text { Azawak } \\
\text { Means } \pm \text { SE }\end{array}$ & $\begin{array}{c}\text { Crossbred } \\
\text { Means } \pm \text { SE }\end{array}$ & $\begin{array}{c}\text { Girolando } \\
\text { Means } \pm \text { SE }\end{array}$ & Sig \\
\hline \multirow{4}{*}{ A. variegatum } & Bulls & $2.29 \pm 0.54^{\mathrm{a}}$ & $2.50 \pm 0.40^{\mathrm{a}}$ & $1.41 \pm 0.60^{\mathrm{a}}$ & $4.75 \pm 1.73^{\mathrm{a}}$ & NS \\
\hline & Cows & $4.41 \pm 1.14^{\mathrm{a}}$ & $1.33 \pm 0.38^{\mathrm{b}}$ & $1.79 \pm 0.42^{\mathrm{ab}}$ & $4.20 \pm 0.90^{\mathrm{a}}$ & $* *$ \\
\hline & Calves & $1.29 \pm 0.35^{\mathrm{ab}}$ & $0.66 \pm 0.26^{\mathrm{b}}$ & $1.37 \pm 0.37^{\mathrm{ab}}$ & $2.25 \pm 0.48^{\mathrm{a}}$ & * \\
\hline & Velles & $0.20 \pm 0.08^{\mathrm{b}}$ & $1.00 \pm 0.25^{\mathrm{b}}$ & $0.54 \pm 0.24^{\mathrm{b}}$ & $1.75 \pm 0.36^{\mathrm{a}}$ & $* * *$ \\
\hline \multirow{4}{*}{ R. microplus } & Bulls & $25.37 \pm 6.84^{\mathrm{a}}$ & $38.62 \pm 12.99^{\mathrm{a}}$ & $32.54 \pm 10.57^{\mathrm{a}}$ & $54.79 \pm 19.66^{\mathrm{a}}$ & NS \\
\hline & Cows & $17.79 \pm 5.22^{\mathrm{a}}$ & $21.37 \pm 6.74^{\mathrm{a}}$ & $21.87 \pm 7.86^{\mathrm{a}}$ & $39.79 \pm 13.38^{\mathrm{a}}$ & NS \\
\hline & Calves & $2.95 \pm 0.90^{\mathrm{a}}$ & $10.20 \pm 4.19^{\mathrm{a}}$ & $11.91 \pm 5.01^{\mathrm{a}}$ & $19.16 \pm 5.75^{\mathrm{a}}$ & NS \\
\hline & Velles & $1.29 \pm 0.42^{\mathrm{b}}$ & $5.12 \pm 1.85^{b}$ & $11.50 \pm 5.04^{\mathrm{ab}}$ & $21.87 \pm 6.65^{\mathrm{a}}$ & $* *$ \\
\hline \multirow{4}{*}{ Hyalomma spp. } & Bulls & $0.54 \pm 0.15^{\mathrm{b}}$ & $0.12 \pm 0.06^{b}$ & $0.25 \pm 0.09^{b}$ & $1.16 \pm 0.30^{\mathrm{a}}$ & $* * *$ \\
\hline & Cows & $0.66 \pm 0.14^{\mathrm{b}}$ & $0.25 \pm 0.10^{\mathrm{b}}$ & $0.37 \pm 0.11^{\mathrm{b}}$ & $1.58 \pm 0.50^{\mathrm{a}}$ & $* *$ \\
\hline & Calves & $0.20 \pm 0.10^{\mathrm{b}}$ & $0.16 \pm 0.07^{\mathrm{b}}$ & $0.20 \pm 0.08^{\mathrm{b}}$ & $1.20 \pm 0.35^{\mathrm{a}}$ & $* * *$ \\
\hline & Velles & $0.16 \pm 0.13^{b}$ & $0.25 \pm 0.10^{\mathrm{b}}$ & $0.45 \pm 0.13^{\mathrm{ab}}$ & $0.79 \pm 0.21^{\mathrm{a}}$ & * \\
\hline
\end{tabular}

SE: standard error; ${ }^{\mathrm{NS}} P>0.05 ;{ }^{*} P<0.05 ;{ }^{* *} P<0.01 ;{ }^{* * *} P<0.001 . \mathrm{a}, \mathrm{b}$, and ab: means with the same letters within lines are not significantly different, $P>0.05$ (averages of the same line, followed by the same letter, do not differ significantly at the $5 \%$ level).

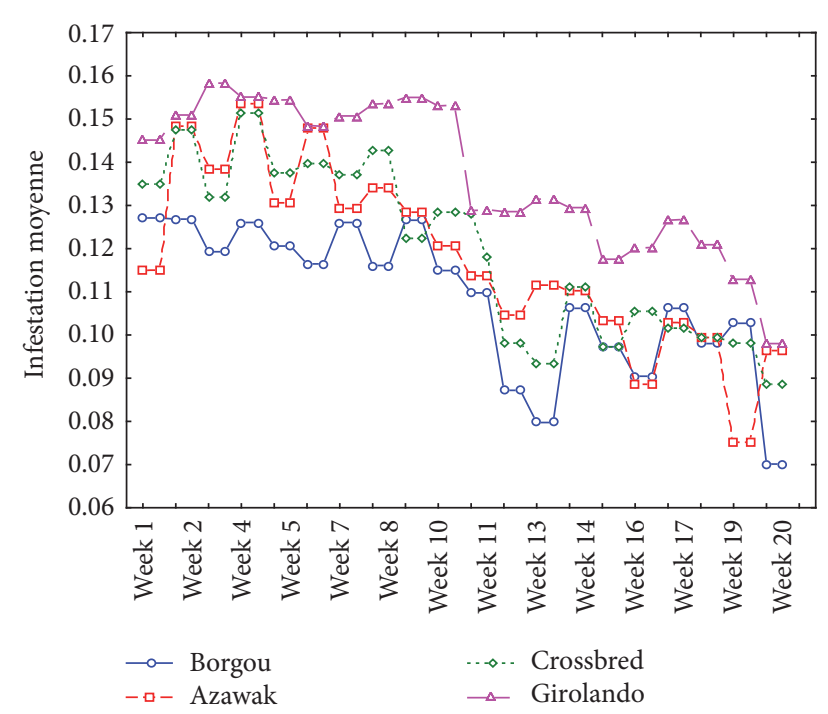

Figure 2: Relative attraction of cattle on ticks (Amblyomma variegatum, Rhipicephalus microplus, and Hyalomma spp.). Mean infestation $=[\log ($ tick counts +1$)] /$ number of animals of the breed.

$0.001)$ and velles $(P<0.05)$ (Table 6). From this analysis, we note a great infestation of tick's $R$. microplus on the farm during our study. Males of Girolando, Azawak, and Crossbred race are the most exposed as well as females. The calves and calves of the Borgou were less infested by R. microplus.

Tick parasitic charge was influenced by time and season. A highest attractiveness was observed during the first ten (10) weeks which correspond to the rainy season, period of tick abundance. But, during the last ten (10) weeks, a drop in attractiveness was noted. The highest attractivity was noted in the Girolando and lower in the Borgou (Figure 2).

\section{Discussion}

In this study, 9049 ticks were collected and three tick's species were identified, including $R$. microplus, which was the most abundant (89.28\%) with 126.23 as mean parasitic intensity. This revealed a heterogeneous distribution, reason of its parasitic ubiquity. The mean parasitic intensity is high ( $I>100)$, because the tick can be found on cattle at all stages of development, including larvae, nymph, and adults. In addition, it was a monotonic monophasic species with strong parasitic selectivity for Girolando. It has also a very short breeding cycle and a high ecological adaptation capacity [14]. On the other hand, A. variegatum, despite its capacity to infest the cattle, has a lower mean parasitic intensity (10 $<I<50)$. The same observation was made with Hyalomma spp. whose mean parasitic intensity was very low $I<10$. These ticks have a development cycle that takes place on several hosts and they are less invasive than $R$. microplus [15]. Although consistent with other findings [16], our results showed opposite tendency compared to what was reported few years ago with regard to tick species distribution and abundance around Benin. In fact, $A$. variegatum was the most abundant and widely distributed species in northern Benin [17]. Several authors have, however, revealed an abundance of A. variegatum in cattle farms [18]. Studies carried out in northern Benin prior to the arrival of the Girolando on the Opkara breeding farm did not mention the presence of $R$. microplus [17]. R. microplus was accidentally introduced in Benin particularly on Kpinnou farm and later on Opkara farm through the importation of Brazilian Girolando cattle [19]. Opkara farm constitutes a pole of diffusion of $R$. microplus in the North of Benin. Actually R. microplus is hydrophilic and develops easily in humid climate. Hence the environmental conditions at Opkara (rainfall higher than $1200 \mathrm{~mm}$ and mean annual temperature varying between 26 and $27^{\circ} \mathrm{C}$ ) are favorable to the evolution of this tick. Due to the lack of grassland in the study area, cattle are taken to the surrounding woody forest for grazing which increases contact between ticks and animals as the existing microenvironment in woody forest is highly favorable for tick development [20]. This may justify the high infestation rate noted. In this study, index of infestation was used to 
assess the attraction exerted by each animal on the ticks. The observed variability between animals in the four breeds suggests that ability to attract ticks may be directly linked to genetic factors and indirectly linked to environmental factors and herd management. Animals at the head or tail of the herd are less exposed to ticks than those in the middle of the herd. This may influence infestation rate in between breeds as the position of individual breeds when grazing is not standard. The introduction of $R$. microplus completely changed the pattern of ticks infestation in Benin [18]. The infestation of different animals by R. microplus showed a large intraracial variation $(P<0.001)$. The Borgou cattle were the most resistant and the Girolando cattle the least resistant to ticks. It was clear that tick resistance varies not only from one anatomical region to another, but, more markedly, from one breed to another. The Borgou have the smallest mean tick infestation for all ticks species including $A$. variegatum, R. microplus, and Hyalomma spp., therefore less susceptible than all other breeds of cattle. Borgou cattle are crossbreeding product of the short-horned bulls of West Africa (Somba or Lagunaire) and the Zebu White Fulani (Bos taurus) $\mathrm{x}$ zebus (Bos indicus) [21]. Previous studies have shown that taurine (Bos taurus) and zebu (Bos indicus) were tick-resistant [22]. Hence this may explain why Borgou cattle are less sensitive to ticks infestation. Bulls are again in Australia, and zebu were imported because of their resistance to ticks and their adaptation to heat. They were used to increase the performance of previously introduced bulls [23]. Bulls are tick-resistant as they release $90 \%$ of the larvae after scratching after 24 hours [24]. During taurine infestation by tick larvae, histamine released by mast cells is transported to the site of attachment of the tick by eosinophils. It is noted that the resistance of the taurine is correlated to the concentration of eosinophils at the site of attachment of the tick. Eosinophils therefore play a role in tick rejection by concentrating histamine released by mast cells at the tick attachment point [25]. The concentration of this mediator at the cutaneous level is correlated to the scratching behavior on the part of the host [26]. In Australia, zebu have been imported because of their resistance to ticks and their adaptation to heat. They were used to increase the performance of previously introduced bulls [23]. Borgou was being a cross between taurine and zebu, their response to tick infestation was linked to the presence of a high percentage of the zebu/taurine gene in their organisms. African cattle are more resistant to ticks than exotic bovines [24]. This is consistent with our results as in this study Girolando cattle, which were also crossbred products of Gyr (Bos indicus) and Holstein (Bos taurus) were more susceptible to ticks than other local breeds of cattle. The works carried out by Jonsson et al. [27] showed a low level of resistance of Holstein-Friesian breed to ticks, particularly $R$. microplus, which usually results in high morbidity and mortality [28]. The Girolando cattle imported to Benin are facing adaptation issues (thermal stress, climatic phenomena) and nutritional deficiencies that weaken their organism and make them vulnerable to ticks. The other two breeds taken into account in this study are Borgou x Girolando products and Azawak cattle. Azawak cattle are originally from Niger and are known for their resistance to heat. These two breeds are less infested than Girolando cattle. The number of ticks counted per body region varied significantly. The head, neck, and ventrogenital region of Borgou and Girolando cattle have the greater number of $A$. variegatum. However, $R$. microplus was abundant at the head, ears, and tails as well as the ventrogenital regions. Our results were similar to those obtained by Awa et al. [29] who have shown a preference for ticks in the ventrogenital and abdominal region. The relation between tick rostrum size and infested region was reported by Farougou et al. [17]. In this research, majority of $R$. microplus was found in the ventrogenital region of Borgou, Azawak, Crossbred, and Girolando $(P<0.01)$. R. microplus prefers thin-skinned regions because it is brevirostre. However, $A$. variegatum and Hyalomma spp. can be seen everywhere. This finding is in line with that of Barre and Uilenberg [30]. The difference of infestation may be associated with competition between different tick species; for example, the tick Rhipicephalus microplus is an invasive species that has higher ecological adaptability capacity and can gradually replace other ticks species [18]. This study also revealed the influence of animal age on tick infestation. Calves are less infested than bulls and cows. These results were similar to those obtained by Matzigkeit [31], which show that young cattle were more resistant to ticks than older ones and young [32]. It should also be noted that the management of young cattle can contribute to the reduction of infestation. They were sometimes kept in a stall, reducing the risk of their exposure to ticks in pastures. The parasitic load of male's cattle was higher than that of the females. This difference can be explained by the stimuli and the tick tropism. The amount of carbon dioxide $\left(\mathrm{CO}_{2}\right)$ emitted is the first determining factor in the detection of the presence of the host by the ticks [33]. Since this quantity was proportional to the size of the host, male bovines emit much more gas than the female bovine animals, which explains the high parasitic load found at their level [34]. These results were contrary to the results reported by Gharbi et al. [35] which show that female cattle were more infested than males. However, they agree with the observations of Chartier et al. [15], who reported that ticks were usually more frequent on bulls than on cows. It would be beneficial to take into account all these factors in the selection of breeds to reduce the damage by the ticks to infested animals.

\section{Conclusion}

Ticks, due to their direct impact and the diseases they transmit, are one of the major constraints to the development of cattle breeding in northern Benin. The study carried out in the locality of Opkara on the infestation of cattle by ticks allowed us to identify three endemic species of ticks including A. variegatum, R. microplus, and Hyalomma spp. Girolando cattle are the most sensitive to all ticks species. Abundance of $R$. microplus once again testifies its adaptability and invasiveness. It may spread all over the country and even reach neighboring countries. Taking into account the information obtained from this work, it would be possible to integrate genetic approaches to tick control in order to improve the health management of cattle herds. 


\section{Conflicts of Interest}

The authors declare that there are no conflicts of interest regarding the publication of this paper.

\section{Acknowledgments}

The authors are grateful to the Ministry of Higher Education and Scientific Research of Benin, through the Doctoral Support Program.

\section{References}

[1] MAEP (Ministère de l'Agriculture de l'Elevage et de la Pêche), Plan Stratégique De Relance Du Secteur Agricole (PSRSA) Cotonou, République du Bénin, 2011.

[2] S. H. Onu and T. Z. Shiferaw, "Prevalence of ectoparasite infestations of cattle in Bench Maji Zone, southwest Ethiopia," Veterinary World, vol. 6, no. 6, pp. 291-294, 2013.

[3] R. E. Yessinou, Y. Akpo, C. Adoligbe et al., "Resistance of tick Rhipicephalus microplusto acaricides and control strategies," Journal of Entomology and Zoology Studies, vol. 4, no. 6, pp. 408414, 2016.

[4] E. Castro-Janer, J. R. Martins, M. C. Mendes, A. Namindome, G. M. Klafke, and T. T. S. Schumaker, "Diagnoses of fipronil resistance in Brazilian cattle ticks (Rhipicephalus (Boophilus) microplus) using in vitro larval bioassays," Veterinary Parasitology, vol. 173, no. 3-4, pp. 300-306, 2010.

[5] F. M. Ferreira, C. C. Delmonte, T. L. P. Novato et al., "Acaricidal activity of essential oil of Syzygium aromaticum, hydrolate and eugenol formulated or free on larvae and engorged females of Rhipicephalus microplus," Medical and Veterinary Entomology, 2017.

[6] M. C. Mendes, C. K. P. Lima, A. H. C. Nogueira et al., "Resistance to cypermethrin, deltamethrin and chlorpyriphos in populations of Rhipicephalus (Boophilus) microplus (Acari: Ixodidae) from small farms of the State of São Paulo, Brazil," Veterinary Parasitology, vol. 178, no. 3-4, pp. 383-388, 2011.

[7] J. W. Magona, J. Walubengo, and F. Kabi, "Response of Nkedi Zebu and Ankole cattle to tick infestation and natural tickborne, helminth and trypanosome infections in Uganda," Tropical Animal Health and Production, vol. 43, no. 5, pp. 1019-1033, 2011.

[8] R. C. Mattioli, K. Dampha, M. Bah, A. Verhulst, and V. S. Pandey, "Effect of controlling natural field-tick infestation on the growth of N'Dama and Gobra zebu cattle in the Gambia," Preventive Veterinary Medicine, vol. 34, no. 2-3, pp. 137-146, 1998.

[9] A. M. G. Ibelli, A. R. B. Ribeiro, R. Giglioti et al., "Resistance of cattle of various genetic groups to the tick Rhipicephalus microplus and the relationship with coat traits," Veterinary Parasitology, vol. 186, no. 3-4, pp. 425-430, 2012.

[10] E. K. Piper, L. A. Jackson, N. H. Bagnall, K. K. Kongsuwan, A. E. Lew, and N. N. Jonsson, "Gene expression in the skin of Bos taurus and Bos indicus cattle infested with the cattle tick, Rhipicephalus (Boophilus) microplus," Veterinary Immunology and Immunopathology, vol. 126, no. 1-2, pp. 110-119, 2008.

[11] S. C. Dossa, G. P. Kaaya, S. Essuman, A. Odulaja, and R. G. K. Assoku, "Acquisition of resistance to the tick Amblyomma variegatum in Boran cattle, Bos indicus and the effects of
Trypanosoma congolense and Babesia bigemina on host resistance," Veterinary Parasitology, vol. 62, no. 3-4, pp. 317-330, 1996.

[12] A. R. Walker, A. Bouattour, J. J. Camicas et al., "Ticks of domestic animals in Africa: a guide to identification of species," Bioscience Report, Edinburgh Scotland, pp. 1-1221, 2003.

[13] C. Bilong-Bilong and T. Njiné, "Dynamique de populations de trois monogènes parasites d'Hemichromis fasciatus (Peters) dans le lac municipal de Yaoundé et intérêt possible en pisciculture intensive," Annales de la Faculté des Sciences de l'Université de Yaoundé I, Série Sciences Naturelles et Vie, vol. 34, pp. 295303, 1998.

[14] O. M. Boka, M. Madder, Y. L. Achi, Y. Y. Kaboret, and D. Berkvens, "Modelisation du remplacement de Rhipicephalus (Boophilus) decoloratuspar Rhipicephalus (Boophilus) microplus, une tique émergente en Côte d'Ivoire," European Scientific Journal, vol. 10, no. 30, 2014.

[15] C. Chartier, J. Itard, P. C. Morel, and P. M. Troncy, "Précis de parasitologie vétérinaire tropicale," Collection Universités Francophones, vol. 67, article 02, 2000.

[16] E. M. de Clercq, S. O. Vanwambeke, M. Sungirai, S. Adehan, R. Lokossou, and M. Madder, "Geographic distribution of the invasive cattle tick Rhipicephalus microplus, a country-wide survey in Benin," Experimental and Applied Acarology, vol. 58, no. 4, pp. 441-452, 2012.

[17] S. Farougou, M. Kpodekon, H. Adakal et al., "Abondance saisonniere des tiques (Acari: Ixodidae) parasites des ovins dans la region meridionale du Benin," Revue de Médecine Vétérinaire, vol. 158, no. 12, pp. 627-632, 2007.

[18] Y. S. Kwak, T. Y. Kim, S.-H. Nam et al., "Ixodid tick infestation in cattle and wild animals in Maswa and Iringa, Tanzania," The Korean Journal of Parasitology, vol. 52, no. 5, pp. 565-568, 2014.

[19] M. Madder, E. Thys, D. Geysen, C. Baudoux, and I. Horak, "Boophilus microplus ticks found in West Africa," Experimental and Applied Acarology, vol. 43, no. 3, pp. 233-234, 2007.

[20] M. Madder, N. Speybroeck, A. Bilounga, D. Helleputte, and D. Berkvens, "Survival of unfed Rhipicephalus appendiculatus and Rhipicephalus zambeziensis adults," Medical and Veterinary Entomology, vol. 19, no. 3, pp. 245-250, 2005.

[21] A. M. Domingo, "Contribution à l'étude de la population bovine des Etats du golfe du Bénin," CGSpaceA Repository of Agricultural Research Outputs, 1976.

[22] A. V. Schleger, D. T. Lincoln, and A. S. Bourne, "Arteriovenous anastomoses in the dermal vasculatureof the skin of bos taurus cattle, and their relationship with resistance to the tick, boophilus micro plus," Australian Journal of Biological Sciences, vol. 34, no. 1, pp. 27-35, 1981.

[23] M. Brossard, "The use of vaccines and genetically resistant animals in tick control," Revue Scientifique et Technique de l'OIE, vol. 17, no. 1, pp. 188-199, 1998.

[24] N. N. Jonsson, E. K. Piper, and C. C. Constantinoiu, "Host resistance in cattle to infestation with the cattle tick Rhipicephalus microplus," Parasite Immunology, vol. 36, no. 11, pp. 553-559, 2014.

[25] T. Wada, K. Ishiwata, H. Koseki et al., "Selective ablation of basophils in mice reveals their nonredundant role in acquired immunity against ticks," The Journal of Clinical Investigation, vol. 120, no. 8, pp. 2867-2875, 2010.

[26] K. Thutwa, Comparison of Genetic And Immunological Responses to Tick Infestation between Three Breeds of Sheep in South Africa, University of the Free State, 2016. 
[27] N. N. Jonsson, A. L. Matschoss, P. Pepper, P. E. Green, and J. Ansell, "Resistance of Holstein-Friesian cows to infestation by the cattle tick (Boophilus microplus)," Veterinary Parasitology, vol. 89, no. 4, pp. 297-305, 2000.

[28] D. Muhanguzi, K. Picozzi, J. Hatendorf et al., "Prevalence and spatial distribution of Theileria parva in cattle under croplivestock farming systems in Tororo District, Eastern Uganda," Parasites \& Vectors, vol. 7, no. 1, article no. 91, 2014.

[29] D. N. Awa, H. Adakal, N. D. D. Luogbou, K. H. Wachong, I. Leinyuy, and M. D. Achukwi, "Cattle ticks in Cameroon: Is Rhipicephalus (Boophilus) microplus absent in Cameroon and the Central African region," Ticks and Tick-borne Diseases, vol. 6, no. 2, pp. 117-122, 2015.

[30] N. Barré and G. Uilenberg, "Spread of parasites transported with their hosts: case study of two species of cattle tick," Revue Scientifique et Technique-Office International Des Epizooties, vol. 29, no. 1, pp. 147-149, 2010.

[31] Matzigkeit, Médecine vétérinaire: lutte contre les ectoparasites tropicaux, IMT Prince Léopold, Anvers, Belgique, 1997.

[32] A. M. Sassa, C. A. Etchike, H. Gambo, and A. N. Nloga, "Inventaire et prévalence des tiques du bétail dans les élevages de l'Adamaoua au Cameroun," Revue Africaine de Santé et de Productions Animales, vol. 12, no. 1, 2014.

[33] W. Wanzala, N. F. K. Sika, S. Gule, and A. Hassanali, "Attractive and repellent host odours guide ticks to their respective feeding sites," Chemoecology, vol. 14, no. 3-4, pp. 229-232, 2004.

[34] H. Musa, S. Jajere, N. Adamu et al., "Prevalence of Tick Infestation in Different Breeds of Cattle in Maiduguri, Northeastern Nigeria," Bangladesh Journal of Veterinary Medicine, vol. 12, no. 2, pp. 161-166, 2014.

[35] M. Gharbi and M. Aziz Darghouth, "A review of Hyalomma scupense (Acari, Ixodidae) in the Maghreb region: From biology to control," Parasite, vol. 21, article no. 2, 2014. 


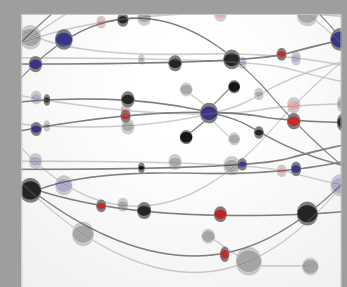

The Scientific World Journal
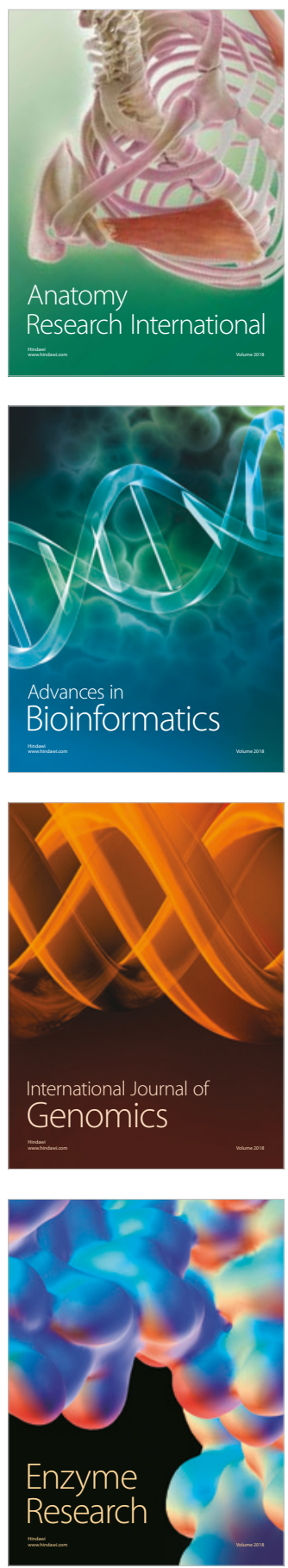
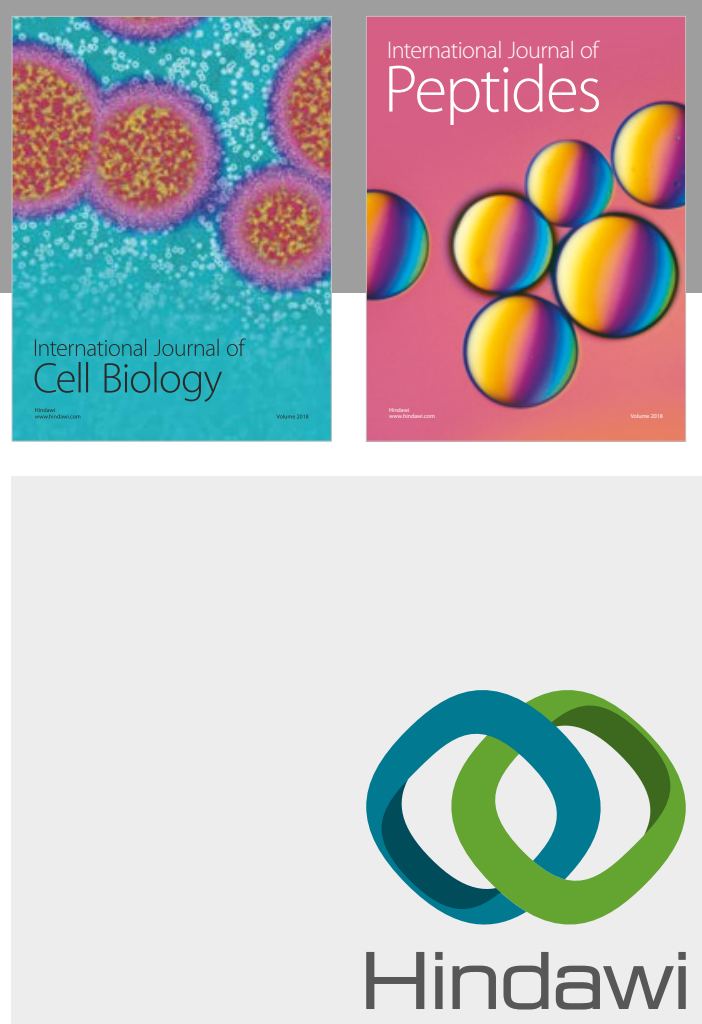

Submit your manuscripts at

www.hindawi.com
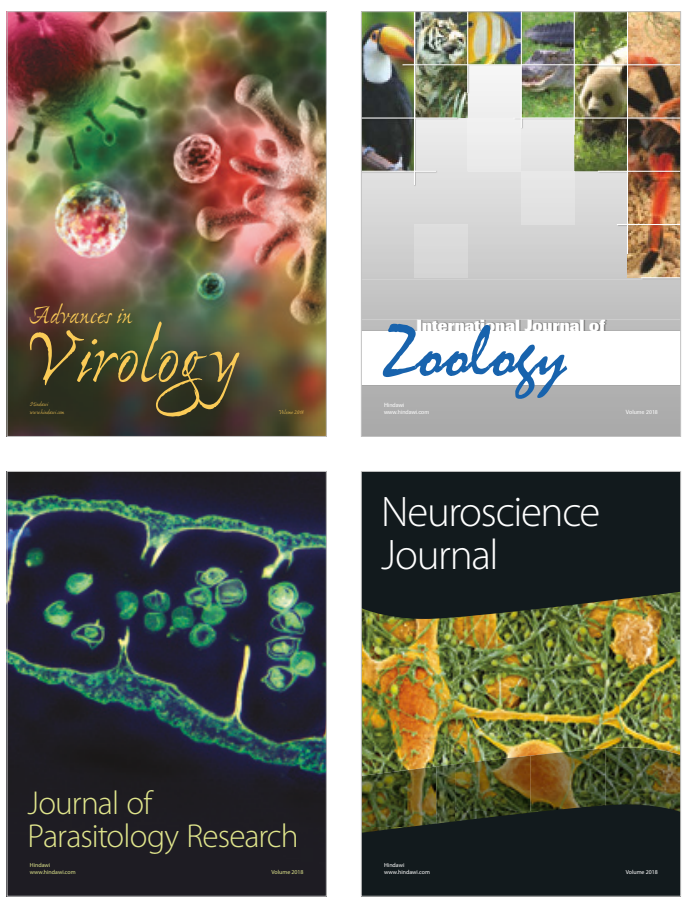
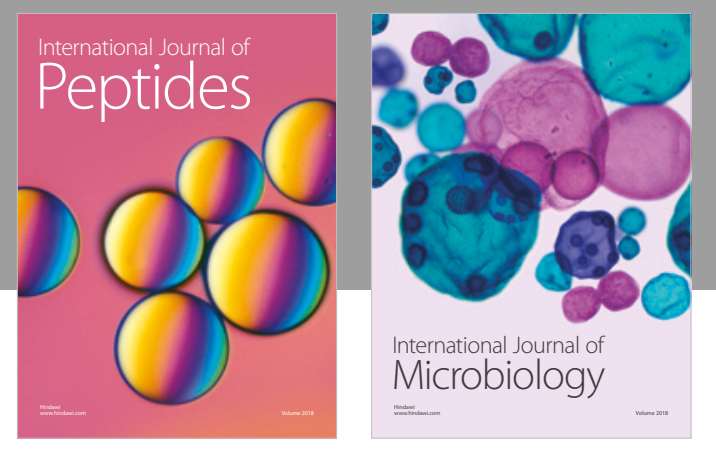

nternational Journal of Microbiology
Journal of
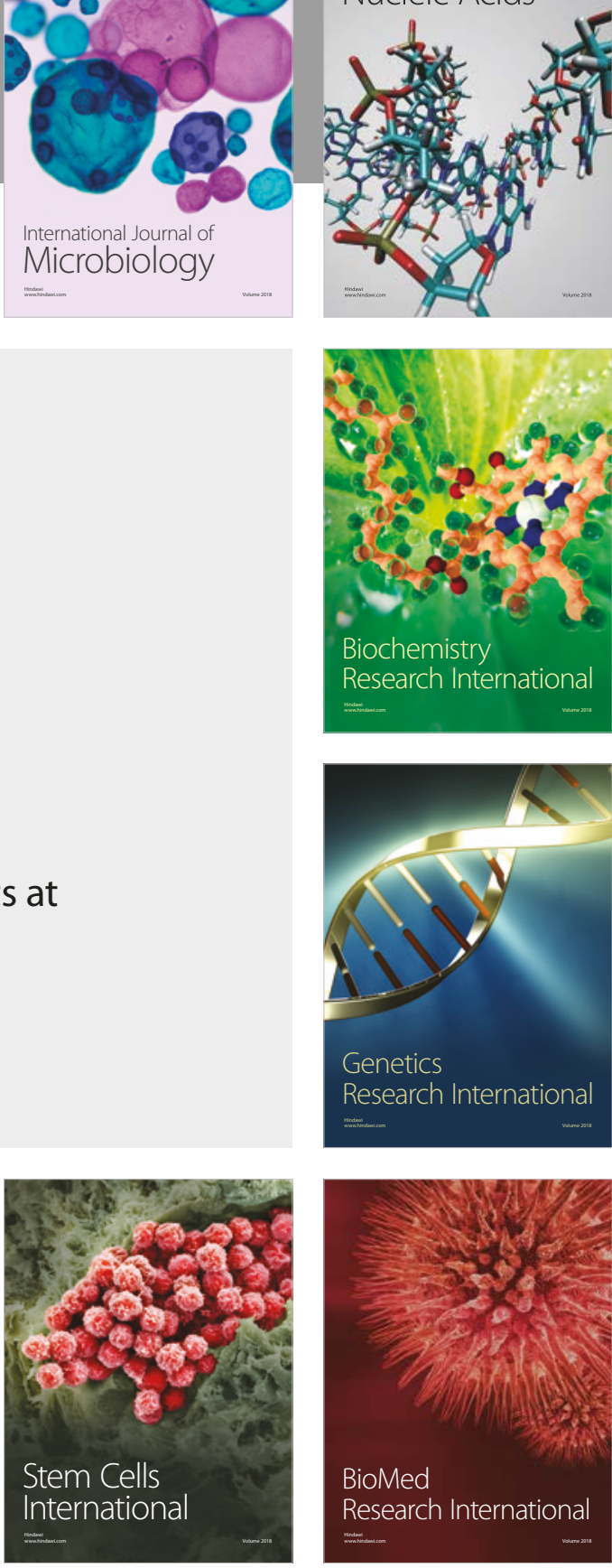
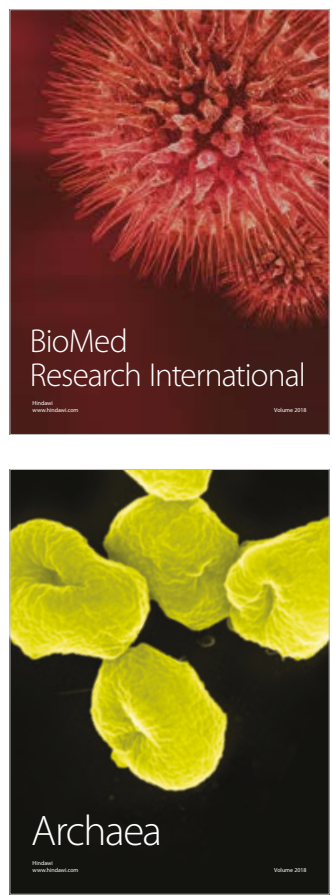